\title{
PKC-beta Inhibitor MS-553
}

National Cancer Institute

\section{Source}

National Cancer Institute. PKC-beta Inhibitor MS-553. NCI Thesaurus. Code C148422.

An orally available inhibitor of the beta-isoform of protein kinase $C(P K C)$, with potential immunosuppressive and antineoplastic activities. Upon oral administration, PKC-beta inhibitor MS-553 selectively binds to and inhibits PKC-beta, which prevents the activation of PKC-beta-mediated signaling pathways. This may lead to the induction of cell cycle arrest and apoptosis in susceptible tumor cells. PKC-beta, a serine/threonine protein kinase overexpressed in certain types of cancer cells, is involved in tumor cell differentiation, proliferation, invasion and survival. 